\title{
Эпоха 90-х
}

\section{Социальный контракт в эпоху 90-х1}

DOI: 10.19181/inter.2019.18.4

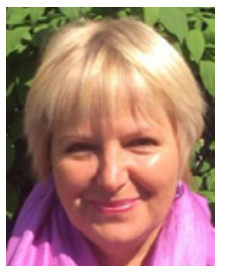

\section{Елена Рождественская *}

В статье рассматривается проблематика менявшегося социального контракта в 1990-е гг. Совмещается несколько уровней анализа: реконструкция эпохи 90-х по следам опросов общественного мнения и качественный анализ нарративов об этой эпохе представителей различных социальных групп (рабочих, наемных работников / госслужащих, предпринимателей). Если опросы общественного мнения тематизируют важнейшие события эпохи, которые составили историческую память поколения, участвовавшего в переменах российского общества, то нарративы 90-х содержат описание опыта и рефлексию социальных акторов относительно лимитов и возможностей этой эпохи. Концептуальная рамка исследования описывает понятие социального контракта как баланса ожиданий между исполняющими его индивидами и социальными институтами. Социальный контракт операционализируется в виде набора стратегий действия, которые были реализованы индивидами и составляют предмет их воспоминаний в режиме биографического интервью. В результате исследования осуществлена спецификация для представителей упомянутых социальных групп различных социальных контрактов, которые претерпели девальвацию и видоизменились в течение 1990-хгг.

Ключевые слова: эпоха 90-х, социальный контракт, трудовой контракт, социальные группы, биографические интервью

${ }^{1}$ Данная публикация подготовлена при финансовой поддержке Фонда «Президентский центр Б. Н. Ельцина» в рамках проекта «Социальная история России (1990-е годы)».

* Рождественская Елена - доктор социологических наук, профессор департамента социологии Национального исследовательского университета «Высшая школа экономики»; ведущий научный сотрудник Института социологии Федерального научно-исследовательского социологического центра Российской академии наук (ФНИСЦ РАН), e-mail: erozhdestvenskaya@hse.ru 


\section{Введение}

Разрывы в истории обостряют интерес к прошлому, к проблеме связи времен, заставляют изобретать новые образы прошлого, которые позволили бы восстановить «распавшуюся связь времен». Современный интерес к прошлому вызвал переосмысление основных проблем, связанных с пониманием истории и памяти. Это коснулось, в основном, следующих направлений. Во-первых, единое восприятие времени сменилось осознанием того, что не существует как единого времени (школа «Анналов»), так и единой культуры восприятия времени (Леви-Стросс): в разных культурах и на разном уровне социальности прошлое (или история) воспринимаются по-разному. Концептуальные представления о прошлом связаны с особенностями культуры отдельных обществ, классов и субкультур. При этом существуют отдельные социальные общности, эмоционально более чувствительные к проблеме времени, где история (прошлое) становится чем-то вроде внутреннего двигателя развития и прогнозирования на будущее (Артог, 2004).

Вторая особенность - отношение «прошлое-настоящее». В интересе к прошлому, считают исследователи, центральным является интерес к настоящему как точке, где пересекаются восприятие «опыта» (прошлого) и представления о будущем - «горизонты ожидания». Это своеобразный диктат настоящего времени, которое ставит себе на службу как прошлое, так и будущее (Артог, 2004). Интерес к прошлому возвращается в новом виде: с его помощью пытаются освятить собственную теперешнюю идентичность: через память, наследие, юбилеи, исторические празднества утверждаются и переосмысляются ключевые координаты осознания себя как общности. По мнению польского историка Едловски, память представляет собой «временное поле, в котором присутствует диалектическое единство прошлого, настоящего и будущего: с одной стороны, поток жизни во времени прошлого и настоящего предопределяет будущее, с другой стороны, именно настоящее "придает форму" прошлому, реконструируя и интерпретируя его с целью отбора всего того "значимого", что может пригодиться в будущем» (Edlowski, 2001). Вследствие этого, политика памяти становится аргументом для обеспечения сегодняшних интересов политических элит. Воспоминание, переработка или забвение - три точки одного континуума, который мы называем памятью. «Непрошедшее» прошлое - это прошлое, которое подвергается интерпретациям, наделяя события определенными смыслами, и эти смыслы зависят от современности (Вильцер, 2005).

Социологический интерес к феномену памяти с позиции «настоящего» продиктован поиском механизмов, порождающих и поддерживающих социальность. Память о прошлом необходима для социального взаимодействия, поскольку она, в качестве культурно-обработанного продукта, закладывается в представление о «должном» характере социального действия. Рефлексивное применение ресурсов памяти, более того, стратегическое распоряжение ими приводит к тому, что происходит «приписывание явлениям настоящего некоторого дополнительного значения. Это свидетельствует 
о прошлом, отсылает к прошлому, что противоположно "синхронизированному", социально согласованному как одновременное настоящему» (Филиппов, 2004: 49). Как ресурс социального взаимодействия, память подпитывает его информационно, конструирует значения для настоящего, вызывает эмоции и сопереживания и, наконец, косвенно, через социальнополитические институты, обеспечивает социальную идентификацию.

Что вытекает из такого подхода к пониманию социальной памяти, простимулированного рефлексией критического дискурса? Какие следуют возможности для социологического анализа? На наш взгляд, принципиальна позиция о множественности «памятей» как представлений о прошлом в сознании разных социальных акторов, наделенных своим социальным опытом и интересами в настоящем. И поскольку универсальной памяти не существует, то «носителями коллективной памяти являются группы, ограниченные в пространстве и времени» (Хальбвакс, 2005). Социальная память поддерживает групповые идентичности. Она понимается как история «коллективных ментальностей», по метафорическому выражению П. Нора, которые могут не совпадать как друг с другом, так и с официальным дискурсом.

В отношении к избранному объекту исследования - эпохе 90-х, событийность которого будет представлена в первой части статьи на уровне опросов общественного мнения, во второй части мы рассмотрим теоретическую рамку социальной контрактации, с помощью которой фреймируем социальный опыт эпохи 90-х. В завершение мы акцентируем внимание на линзе воспоминаний, то есть дискурсе вербализации пережитого опыта эпохи перемен представителями различных социальных групп, описывающих переломные моменты своей жизни. Обращение к индивидуальному опыту рассказчиков не должно затенять того важного обстоятельства, что акторы прибегают не только к социально выработанному языку описания социального опыта, но также оперируют резервуаром воспоминаний, который нельзя отнести только к ресурсам индивидуальной памяти, но также и к гранд-нарративам их социальной группы, медийным дискурсам прошедшего времени, опосредующим уровень индивидуальных воспоминаний и оценки массового сознания.

В 1990-х гг. экономика СССР, а затем и России, переживала сложные трансформации, которые сопровождались инфляцией, резким уменьшением доходов населения, низкими инвестициями, феноменом бартеризации экономики и другими негативными явлениями. Этот период отмечен тяжелыми экономическими реформами для перехода экономики страны от плановой к рыночной: цены были отпущены в свободное плавание, торговля либерализована, стартовала массовая приватизация. То, что уместилось в один абзац, в реальности растянулось на тяжелейшее десятилетие, социальные последствия которого все еще привлекают внимание исследователей. Советский общественный договор, связующий власть и население в его различных социальных сегментах, ощутимым образом девальвировался и подлежал переопределению. С очевидностью, этот процесс затронул все социальные слои и группы меняющегося общества, институциональные основы и повседневность. Реконструкция этого объемного процесса, 
имеющего обширную библиографию, осуществляется нами на нескольких уровнях - в классической метафоре «зеркала общественного мнения» (опросы эпохи 90-х), а также на уровне реконструкции субъективного проживания той эпохи в интервью с представителями различных социальных групп общества, вовлеченных в свои версии общественного договора.

\section{Ключевые события 90-х и реконструкция эпохи в зеркале общественного мнения}

Обращение к общественному мнению на уровне вторичного анализа преследует цель обозначить рамки меняющихся общественных настроений, совмещенных с крупными историческими и социально-экономическими событиями десятилетия 90-х. Эпитеты, которыми награждали 90-е годы соотечественники - «лихие 90-е», «эпоха перемен», «поворотные 90-е», говорят метафорическим языком о турбулентности социальной эпохи, сломе прежних социальных порядков и распаде предыдущей системы. Но, как справедливо заметил И. Клемин, имиджевая лексика не равна проясняющей понимание терминологии (Клемин, 2015). Исследовательский вопрос, как граждане пересобираемой в 90-е годы страны приобретали социальный опыт, переживали перемены, о которых вдохновенно пел Цой, и приспосабливались к меняющимся реалиям жизни, надлежит помещать в различные концептуальные рамки разной степени общности. Поэтому мы привлекаем динамику общественного мнения 90-х годов, реагирующую на самые существенные исторические моменты, чтобы совместить в рамке анализа основные тренды общественной реакции на 90-е годы.

Как отмечает Н. Попов, в массовидной памяти россиян, активная часть жизни которых пришлась на 90-е годы, эпоха Ельцина началась с конкурентной борьбы за лидерство с Горбачевым (Попов, 2015). Он имел образ борца с партийной бюрократией, истинного демократа, «ходившего в народ», разоблачавшего партфункционеров на пленуме ЦК и на Съезде народных депутатов. Популярность и народная поддержка обеспечили ему победу на московских выборах депутатом на Съезд, а затем на выборах президента России. В этом же ряду - победа над ГКЧП во время путча в августе 1991 г. При Ельцине закончилась «эпоха Горбачева», была демонтирована КПСС, стартовал процесс распада СССР, завершившийся соглашениями в Беловежской пуще. По сути, пик популярности Ельцина в народе длился всего пару лет (1990-1991 гг.). Затем, с 1992 г., времени радикальных рыночных реформ, которые приобрели характер «шоковой терапии», начался спад его влияния и популярности в общественном мнении. Его обещания скорого выхода из реформ - он «ляжет на рельсы», если за год ситуация не нормализуется, - не оправдались. Уровень доверия Ельцину снизился с 45\%-50\% в конце 1991 г. до 20\% в конце 1992 г.

Если привлечь отчеты российских поллстеров (ВЦИОМ, БПСИ, Vox Populi, ФОМ и другие), то в зеркале общественного мнения эпоха предстает 
следующим образом. Канун реформ характеризовался в общественном мнении как достаточно стабильный. Основная масса населения не представляла альтернативы своему существованию, большинство пользовалось хоть и минимальным, но стабильным достатком, больше того, жизненный уровень медленно, но рос. Первые опросы ВЦИОМ (Всесоюзного центра изучения общественного мнения под руководством Т. И. Заславской и Б. А. Грушина) показывали, что население в конце 1989 г. считало свое экономическое положение вполне приемлемым и устойчивым. Широкие массы были готовы к восприятию новых перспектив развития страны, но власть не предпринимала усилий по разъяснению, подготовке шоковых реформ, переоценив готовность народа или пренебрегая ею. Однако следующие три года принесли катастрофическое падение производства, дефицит товаров потребления, гигантский рост цен и массовое падение жизненного уровня населения (Попов, 2015).

Это состояние общества Б.А. Грушин описывал следующим образом: «Самое главное из всех произошедших в рассматриваемое время в сфере массовых интересов изменений - изменение, имевшее поистине судьбоносный для истории страны характер, - заключалось, конечно же, в полном крахе всенародной мечты о возможности реализации коммунистической идеи» (Грушин, 2006: 843). Тем не менее, росло смутное понимание необходимости перемен и запрос на изменение системы.

Массовые ожидания были связаны с улучшением материальной стороны жизни, либерализацией экономики, демократическими свободами, но при этом запрос на справедливость и подлинный социализм говорил о неготовности к перспективе капиталистической экономики. Тем не менее, опросы тех лет демонстрируют удовлетворение от сближения с Западом, открытости масс-медиа, дистанцирования от милитаристского образа страны.

Отношение широких слоев к экономическим реформам было достаточно амбивалентно, сохраняя тренды на совершенствование социалистической экономики с государственным контролем и, одновременно, обозначая запрос на более радикальные реформы. Это противоречие тестировал в середине 90-х ВЦИОМ. Отвечая на вопрос: «С чем, прежде всего, связывается у вас представление о "рыночной экономике"?», 54\% назвали «рост цен», затем следовало «расслоение на богатых и бедных» (34\%), и затем - «снижение уровня жизни (23\%). То есть население артикулировало страхи перед капиталистическим способом хозяйствования. Лишь 19\% полагали, что «к рынку надо переходить как можно скорее», в то время как 40\% считали, что «переход к рынку необходим, но делать это следует постепенно», и 16\% высказывали мнение, что «к рынку вообще не следует переходить», при 25\% затруднившихся ответить. Социальная база поддержки шоковой терапии (около 20\%) была существенно узкой. Произошло расслоение на рыночников, бизнес-ориентированных и неосоциалистов, пропорции которых составляли приблизительно 30\%, 13\% и 40\% (ВЦИОМ, 1992).

В начале 90-х сформировалась амбивалентная картина поддержки экономических преобразований. Массы за частную собственность в малом формате бизнеса, на небольших заводах, в легкой и пищевой 
промышленности, но против частной собственности - в тяжелой промышленности и на больших предприятиях, подлежащих государственному контролю. Так, опрос ВЦИОМ 1991 г. (там же) о собственности предприятий обнаружил, что население не поддерживало потерю контроля государства над ключевыми секторами экономики и социальными институтами. При этом очевидна готовность трети населения к приватизации социальных сфер общества, что и не замедлило реализоваться в широком внедрении кооперативов, нацеленных на прибыль посредством прежде всего перепродажи, то есть спекулятивных форм экономической деятельности. Старт рыночных реформ, сопряженных с приватизацией, в 1992 г. имел последствиями резкое падение цен и потерю населением накоплений в сберкассах. Экономический шок от лично переживаемых событий предуготовил и отношение к ваучерной приватизации, которую население воспринимало уже довольно скептично. В середине 1992 г. 44\% опрошенных называли ваучеризацию обманом и «показухой», и только 15\% видели в этой мере возможность того, чтобы «каждый человек мог стать собственником» (там же).

Экономические реформы имели высокую цену для жизненного уклада, привычек, образа жизни подавляющего большинства населения. Существенными факторами переживаний были неуверенность в завтрашнем дне, отсутствие социальной защищенности, доступной медицины и гарантированного образования, перспектив обзаведения жильем, возможностью социальной мобильности. Потребительские ценности и социальные контрасты стали предметом социального рессентимента и ностальгии по советскому уравнительному принципу. Так, в начале 1992 г. 49\% хотели бы, чтобы «все вернулось к состоянию до 1985 года», а 39\% опрошенных с этим не соглашались, и в то же время 50\% ратовали за «более быстрые, решительные перемены», при 32\% считавших, что «нужно действовать более осторожно, осмотрительно» (Попов, 2015).

Отношение к демократии как социальной ценности также претерпело изменения, эволюционировав от очарованности гласностью и публичными свободами, к пониманию того, что у многих возобладало ее понимание как неограниченной личной свободы и вседозволенности. Такая позиция подпитывалась ростом преступности и вела к алармистским установкам, ориентированным, прежде всего, на стабильность и порядок.

Историческая событийность 90-х включает важный момент: победу Ельцина над ГКЧП и Горбачевым в августе 1991 г. В целом, население страны с трудом разбиралось, что происходит в Москве и как к этому относиться. Опросы в Москве в эти дни показали, что треть жителей поддерживали Ельцина, пятая часть - ГКЧП, а половина людей не знали, что происходит, или не могли дать происходящему какую-либо оценку (там же). Динамика отношения населения к ГКЧП в последующие годы показывает, что к 1998 г., по данным Института социологии РАН, число сторонников ГКЧП увеличилось по сравнению с 1991 г. с 17\% до 25\%. А уже в 2006 г., по данным ФОМ, $67 \%$ населения вообще не смогли дать какую-либо оценку относительно пользы или вреда ГКЧП. Тем не менее, Ельцин вышел из этих событий 
победителем. Если на выборах президента РСФСР в июне 1991 г. он получил 43\% голосов избирателей, то в сентябре его поддержка превысила $50 \%$ и продолжала оставаться высокой до начала реформ в 1992 г.

Отношение к распаду СССР в массовом сознании оставалось противоречивым. Необходимость проводимых реформ воспринималась отдельно от сохраняемого единства союзного государства, как показал референдум весны 1991 г., на котором 76\% населения страны высказались за сохранение СССР в «обновленном, демократическом» виде. Но дискурс крушения империи и развала Союза утверждал себя в прессе, к чему подталкивали события в Прибалтике. Опросы самого начала 90-х демонстрируют, что практически треть поддерживала самоопределение республик, но большинство, в той или иной степени, мыслило категориями союзного государства (ВЦИОМ «Архивариус»).

Последующий период, с Ельциным у руля власти, прошел под знаком радикальных и рыночных реформ, отразившихся в общественном мнении как тяжелейший период в жизни российского общества. Опросы фиксировали драматичные оценки населением своего бедственного материального положения в результате реформ: в целом, экономическое положение еще более ухудшилось, основную ответственность за тяжелое положение населения опрошенные возлагали на актуальное руководство; наконец, у правительства не было программы выхода из кризиса (Попов, 2015).

Опыт радикальных реформ имел следствием формирование к середине 90-х общего стереотипного тренда оценки этого периода. Его составляющими стали: общее разочарование и более позитивная оценка предыдущего, социалистического этапа; подмена капитализмом более разделяемой идеи «рыночного социализма»; грабительский характер реформ, их антисоциальный характер; бенефициарами реформ стали нечестные экономические агенты; идея навязанной демократии имеет западное происхождение. Каков был социальный ресурс поддержки дальнейших реформ, показывали опросы общественного мнения в середине 90-х (там же). Убежденных сторонников проводимых реформ было немного, около $10 \%$. Но значимые $41 \%$ рассматривали процесс реформирования на совершенно других основаниях - с социальной защитой населения. При этом $20 \%$ опрошенных выступили однозначно против; наконец, явно дезориентированные $16 \%$ отмолчались.

Успехи администрации президента по двум основным проблемам - военной операции в Чечне и задолженности по зарплатам, а также страх перед возвращением коммунистов во власть, конкурентов на выборах, - положительно сказались на рейтинге популярности Ельцина. В начале июня 1996 г. за Ельцина собирались голосовать столько же людей, сколько за Зюганова. Уже после победы Ельцина на президентских выборах в августе 1996 г. в Хасавюрте был заключен мир с Чечней.

Подытоживая социальные перемены, фиксируемые в ходе опросов общественного мнения, следует отметить динамику политического массового сознания, которое эволюционировало от нарастающего интереса 
к политике и политической мобилизации в начале 90-х годов к постепенно утвердившейся политической апатии, падению интереса к политике, которые были спровоцированы утратой веры народа в возможность реального участия в политической жизни и влияния на принятие властью важных для страны решений. В силу этого массовые взгляды по поводу экономических, политических и социальных проблем характеризуются противоречивостью, непоследовательностью и неожиданным колебаниям от одобрения к отрицанию и обратно. В то же время, тематика опросов структурирует историческую память, создавая вехи последующих воспоминаний, расставляя дискурсивные акценты для означивания пережитой истории.

\section{Теоретическая рамка социальной контрактации}

Подхватывая сюжет означивания, придания смысла и оправдания действий, мы выходим на основные фреймы социального действия, которые заданы не индивидом, а важнейшими социальными институциями и властью, но они поддерживаются индивидами и социальными группами, оправдываются в реализованной биографической практике. Угол зрения или концептуальная позиция, согласно которой общество, социальные связи, институты, социальные группы внутри него функционируют как целая система формальных и неформальных договоренностей между социальными акторами и государством как совокупностью социальных институтов можно назвать социальным контрактом, берущим начало в понятии общественного договора. Самая очевидная оптика рассмотрения системы социальных контрактов относительно стабильно функционирующего общества - дискурс по поводу распределения благ, артикулированное соглашение по поводу этого распределения и обмена этими благами.

В самом общем виде, можно говорить о государственном контракте как социальном обмене безопасности в обмен на лояльность. Государство предоставляет набор благ, включая безопасность, взамен требуя от граждан политической лояльности и выполнения определенных социальных функций. Очевидно, что у различных социальных групп будут складываться различные социальные контракты. Но также очевидно, что нарушение или разбалансирование социальных контрактов, происхождение которых имеет институциональную природу, провоцируется кризисом социальных институтов. Эпохи социальных перемен или слома социальных порядков ставят под сомнение системы функционирующих контрактов, девальвируют их, а также вызывают к жизни новые социальные контракты.

Сложился обширный пласт научной литературы ${ }^{2}$ по социальной контрактации, которую мы привлекаем избирательно для уточнения концептуальной рамки нашего исследования, нуждающегося в фокусировке на фоне

${ }^{2}$ Гайдук К., Дискин И.Е., Кузьмин А. С., Мелвин Н. Дж. и Нечаев В. Д, Курбатова М.В., Левин С.Н., Лавров А., Литвак Дж. и Сазерлэнд Д., Лапина Н. и Чирикова А., Нуреев Р.М., Олейник А. Н., Перегудов С. П., Радаев В. В., Рогов С. М., Сидорина Т. и др. 
нашего интереса к социальной эпохе 90-х. Как фигура песочных часов, социальная реальность позднесоветского формата перетекает в преддверие перестройки, к послесоветскому формату. Узкое горло десятилетия 90-х свернуло широкий набор жизненных стратегий граждан до самого существенного, фактически актуализировав формат выживания. В этом контексте уместно говорить о власти и населении как контрагентах. Поэтому мы фокусируемся в концептуальном плане на понятии социального контракта, его изменения и переопределения.

Исследования контракционизма наследуют идеям об общественном договоре в социальной философии эпохи Просвещения. Во второй половине XX столетия преимущественно западными экономистами, философами и социологами были предложены современные версии контракционизма, использующие модель общественного договора и связанные с ней концептуальные средства для нового осмысления проблематики социальной справедливости, естественных прав, демократии, рационального выбора, для пересмотра принципов современного либерализма и обоснования рациональной социальной политики. Авторы современных концепций общественного договора - американские ученые Дж. Ролз и Р. Дворкин, а также известный экономист, один из авторов теории общественного выбора Дж. Бьюкенен. Их линия аргументации отождествляет процесс заключения общественного договора с реализацией социальной справедливости. Кроме того, тематика социального договора в XX в. оказалась в центре внимания развивающейся институциональной экономики (Д. Норт и Э. де Сото). Проведение радикальных социально-экономических реформ в России привлекло к вопросам контракционизма внимание и отечественных исследователей (экономистов А. Аузана, В. Лексина, Р. Нуреева, Т. Сидориной, Г. Явлинского и др.).

В итоге, консенсуально под социальным контрактом понимается обмен ожиданиями между социальными агентами (группами), предполагающий выполнение определенных ролей, порождающий определенные практики и способы легитимации. Различение вертикальных и горизонтальных социальных контрактов говорит о переплетении макро-, мезо- и микроуровней возможного анализа, создающих сложно устроенную комбинацию структурных, институциональных и социально-групповых факторов, определяющих содержание контракта. Для России, с сильным акцентом на централизацию власти, с очевидностью характерен преимущественно вертикальный социальный контракт, когда представители различных социальных слоев, не имея институциональных переговорных площадок, делегируют свои права на общественные блага и ответственность государству, которое в обмен на это проявление лояльности перераспределяет эти права. Если при горизонтальном социальном контракте различные акторы взаимодействуют друг с другом, то при вертикальном - только с властью. Это взаимодействие можно рассматривать как рациональное, поскольку оно описывается в экономических терминах выгод и издержек, политических терминах - сдержек и противовесов, выбора стратегий реагирования 
в социально-экономических ситуациях (Ролз, Аузан, Новгородцев, Хиршман и др.).

В СССР существовал свой социальный контракт, который начал разрушаться в конце 1980-х гг., его формула хорошо описана Куком: «Режим обеспечивал широкие гарантии полной занятости, а также контроль над ценами и субсидии $<\ldots .>$ наряду с эгалитарной политикой оплаты труда. В обмен на эти блага и столь сильный контроль со стороны государства и предоставленные гарантии экономической и социальной безопасности советские рабочие не протестовали против монопольной власти партии, принимали господство госсобственности в экономике, а также соглашались с политическими устоями авторитаризма» (Cook, 1993: 2). Реформы привели к слому этого контракта и росту дифференциации в оплате труда, реформе цен, а также способствовали появлению частных предприятий; затем последовало социальное расслоение и появление новых классов.

Какова внутренняя дифференциация социального контракта? Типы возможных контрактов, соотносимых, в первую очередь, с трудопоглощающей сферой, - это трудовые контракты (компетенции и труд в обмен на статус и вознаграждение), образовательные (инвестиции в обучение в обмен на квалифицированную трудовую силу), семейные (гетеросексуальная пара балансирует на договоре о ролях кормильца/добытчика и женско-материнской - связанной с рождением детей, уходом и заботой) и т. д.

На институциональном уровне под социальным контрактом понимается групповое имплицитное соглашение о распределении прав и обязанностей между государством и населением, которое может закреплять вертикальную или горизонтальную контрактацию в обществе. Для вертикального социального контракта спецификация прав будет осуществляться непосредственно государством сверху. При горизонтальном социальном контракте, в идеале, его участники равны, а государство является специально созданной структурой для представления и защиты интересов всего населения. Погружение разрабатываемой концепции в проблематику 90-х связано как гипотеза с проблематизацией равновесности концептуальной модели вертикального и горизонтального социальных контрактов, доминации вертикальной его составляющей и, впоследствии, девальвации взаимных контрактационных ожиданий в контексте эпохи 90-х. Эта основная идея и будет операционализирована в ходе эмпирической части исследования.

\section{Методология и объект исследования}

Трансформации социальных контрактов и систем их легитимации в России в эпоху 90-х стали возможны вследствие смены социальных институтов и связанных с ними практик и транслируемого смыслополагания. Беря в фокус исследования активных участников на уровне исполнения социально-трудовых контрактов, мы намерены изучить усилия акторов по реализации доступных им в эпоху 90-х социальных контрактов, их реакцию 
на девальвацию этих контрактов и выстраивание ими контуров новых контрактов.

Таким образом, социологический ракурс этой части исследования освещает переломные для страны годы на примере индивидуальных биографических стратегий, которые направляли еще советских граждан в целом ряде вопросов повседневности - как в общем вопросе выживания, так и в подчиненных вопросах поиска работы, жилья, пропитания, образования, досуга, развлечений, вопросах личного характера. Акцент на понятии стратегий выделяет группу активных деятелей, акторов, которые предпочли сопротивление и строительство новых форм социальной жизни. В соответствии с социологическим подходом, внимание фокусируется на описании реализованных практик (а также отвергнутых социальных возможностей) как структур социального действия в предложенных обстоятельствах, эмоционального переживания исторического времени, а также пострефлексии как попытке осознания социальных перемен, связываемых с 90-ми. Триада в виде стратегий действий, переживаний и рефлексии реконструируется качественными методами в виде глубинного нарративного интервью.

Но какова природа той рациональности, которой руководствуются индивиды, активно занимающиеся какой бы то ни было профессиональной деятельностью, - там, где интересы личности, государства и рынка встречаются в процессе труда? Подобная исследовательская ситуация провоцирует на подход к анализу изучаемого феномена, при котором возможно пренебречь репрезентативностью в пользу типологии. Тем не менее, здесь сохраняется понятие ступенчатой теоретической выборки, в согласии с которой отобранные информанты $(\mathrm{N}=24)$, представляющие возрастную нишу 1950-1965 гг. рождения и различные профессии, будут сравниваться на предмет сходства и различия их стратегий занятости на рынке труда в ходе составления коллекции биографий. В теоретически сформированной выборке представлены такие социальные группы, как рабочие, наемные работники (работники предприятий/организаций, «бюджетники», госслужащие), предприниматели. В кризисную эпоху 90-х представители этих групп в различной степени обладают социальными капиталами для социальной мобильности, которые потенциально возможно конвертировать в новые социальные возможности.

Задача исследователя заключается в том, чтобы из превращенного в текст рассказа информанта о жизни до, во время и после 90-х вычленить значимые для темы исследования поля практик (конкретные биографические пассажи, реальные шаги и состоявшиеся выборы); благодаря обнаруженным стратегиям действий и конструктам смыслополагания реконструировать реализуемые информантами социальные контракты в их динамике.

Преимущество биографического подхода, в данном случае, состоит еще и в том, что темпоральный аспект биографии позволяет проследить трансформацию, иногда резкую и болезненную, таких относительно устойчивых структур личности, как смысловые ориентации и ценности на пути 
приспособления к новому социальному и экономическому порядку и описать контекст этих изменений.

Ниже мы приведем некоторые ярко контурированные биографические кейсы в режиме типологии рассматриваемых социальных групп.

\section{Социально-трудовой контракт для различных социальных групп общества: проблематизация и переопределение}

Социальный контракт рабочих выстраивается в ограниченном поле квалификационных возможностей влиять на трудовую ситуацию и напрямую зависит от ярко выраженной патерналистской ориентации. Поэтому социальные ожидания как часть социального контракта связаны с социальным пакетом: обеспечением качественного медобслуживания, отдыха в заводском профилактории, детского отдыха в летнем лагере (что стало исчезать в кризисное время); возможностями повысить квалификацию, перейти на более оплачиваемое рабочее место; сохранением гарантий прав трудящихся в той или иной форме профсоюзной защиты, закреплением этих прав в коллективном договоре, а также возможностью рассчитывать на справедливую судебную систему. Труд и социальные услуги - формула социального контракта рабочих.

Из нарратива рабочего:

«Я, например, ремонтер резиновых изделий. Моя квалификация никому, кроме этого завода, не нужна. А всем ведь надо кормить семьи, денежки зарабатывать. Автослесарем я тоже работал, знаю, что это такое. Но, чтобы заработать хорошие деньги автослесарем, нужны золотые руки, а в этом масле они ничуть не чище, чем здесь на заводе, да еще бензина надышишься. Хотя выбора много, но я человек не активный, вот моя беда. Миллионом способов можно деньги заработать, но у меня психология немножко другая: я думаю, что мне будет плохого от этого? А с этим ничего не построишь. Сейчас же как бизнесмены думают, что я на этом заработаю? Что мне за это будет - это на 101 месте. Я так не могу» (рабочий, 1962 г. р.).

Здесь в нарративе, если с него «снимать» слои смысла секвенционально, выражена следующая мысль: я привязан квалификацией к заводу - нужно зарабатывать / кормить семью - хорошо зарабатывать я не могу - я не активен - боюсь неудач. В этом тоже есть своя «рациональность»: лучше меньше, зато надежно. Такая «ущемленная» идентичность, провоцирующая неудачи их ожиданием, находит интересное совмещение с профессиональной ситуацией супруги:

«Жена у меня всю жизнь проработала главным бухгалтером, у нее высшее образование. На бухгалтеров спрос тогда был колоссальный. 
Она на нескольких предприятиях проработала. Но потом родила, просидев три года с ребенком, не работала. За это время ее конторы прикрыли. Вернуться некуда было. А сейчас к бухгалтерам большие требования, компьютер знать надо, английский и тому подобное. А навыки-то потеряны. Сейчас она устроилась на другой завод бухгалтером, но там зарплата - кирпичами. За февраль дали зарплату деньгами, а за мартапрель, говорят, берите кирпичом. А ведь надо еще побегать, кому их продать...» (рабочий, 1962 г. р.).

Казалось бы, это нарратив о жене, но мы получаем не историю отношений, а проблематику разрывов в профессиональной карьере, кризиса неплатежей, бартера, тяжело отзывающихся на общей экзистенциальной ситуации семьи, прибавляя еще проблемы перепродажи кирпичей. Важное обстоятельство, что на бухгалтеров тогда был спрос, корреспондирует с собственной профессиональной изоляцией.

Патерналистские ожидания содержатся и в другом нарративе, подчеркивающем ценность формулы «труд плюс социальные услуги»:

«Я в то время (середина 90-х) менял работу. И состоялся у меня такой разговор с начальником. Зачем, мол, ты уходишь, у тебя здесь такое положение. Я говорю ему, понимаешь, я 15 лет работаю на предприятии и за эти годы мне ни разу не подошла очередь даже кроличью шапку получить. А почему такой разговор произошел: жена собралась получать квартиру, я пришел в профком и говорю, вы мне хоть мебель запланируйте. Да-да, говорят, и вот тут через месяц ордер, и узнаю, что приходит стенка мебельная, и вдруг выясняется, что стенка уходит женщине, которая дольше меня на 5 лет работает. И пока я там 15 лет работал, она получает уже вторую стенку. Я завелся, написал заявление и ушел» (рабочий, 1958 г. р.).

Переплетение стажа труда, потребления, регулируемого через профсоюзные каналы, соотнесенность прав на дефицитные товары с местом в заводской иерархии - все это по совокупности привязывало к рабочему месту. Переломный момент, рушащий эту привязанность к предприятию, выглядит иррационально: мебельная стенка против 15 лет, отданных заводу, - но контракт ожиданий и обязательств подтачивался в течение времени. Вот-вот эта система рухнет, и заботить станет уже безработица, страх потерять эту работу:

«Главное, чтобы работа была. У нас второй корпус, человек 5 слесарей. Утром приходишь, обходишь все. Что поломалось за смену, начинаешь делать. Потом текучку начинаешь делать. Обед у нас 45 минут. После обеда то же самое, делаешь запасные детали, если в смену что полетит, чтоб запас был. Так и продолжается как конвейер. То одно делаешь, то другое. Потом приходишь домой, зашел в ванную, руки помыл. 
Перекусил что-то и побежал в гараж... Если бы мне платили приличные деньги, то жена могла бы и дома сидеть с ребенком, как это и полагается. Но ведь рабочий не может содержать семью полностью. Может быть, и может, но это в натяг жить» (рабочий, 1963 г. р.).

\section{Социальный контракт госслужащих}

Социально-трудовой контракт госслужащих отличен от рабочих, прежде всего, ресурсом высшего и специального образования, бюрократическими компетенциями, ценимыми властью, кроме этого - повышенными окладами, наличием премий, возможностями отдыха, лечения, улучшения жилищных условий и пр., - но он также не был защищен в 90-х от кризисов неплатежей и резкого снижения бюджетного финансирования. Более того, для госслужащих относительна защищенность доступа к труду: для многих из них трудовой контракт является краткосрочным, а стимулируемое неплатежами увольнение по собственному желанию легко осуществимо. Для продвижения госслужащих были и остаются важны ценности лояльности и патронирования карьеры:

Из нарратива госслужащей, юриста по образованию (МГУ), директора госагентства по земельным ресурсам. Ее карьера сложилась в «советское» время в органах исполнительной власти, и наработанный капитал связей помог значительно повысить профессионально-статусные позиции в 90-е:

«...просто везде... нужны грамотные люди, которые, безусловно, работают в какой-то команде... Я оказалась в одной команде и поняла, что... важно течение, важно было сохранить какую-то ориентацию, одну, не перебегать из лагеря в лагерь, поскольку были такие ситуации, когда вот именно какая-то двойственность позиций приводила к тому, что человека просто убирали за два дня...» (юрист, 1964 г. р.).

Итак, профессионализм и принадлежность к команде выделяются как значимые факторы продвижения. Понимание профессионализма тесно увязано у рассказчицы с лояльностью, она даже не разделяет их.

«Безусловно компетентный, но не очень лояльный? Таких, наверное, не бывает. Потому что компетентность - категория, которая привязывается, допустим, главный бухгалтер должен понимать проблемы, которые ставит руководство, и решать их вместе с руководством... Иначе это счетовод. Профессионализм настолько всеобъемлющее понятие, которое включает умение общаться с людьми и умение конкретизировать задачи. Возможность установить нормальные, человеческие контакты - это одно из самых главных качеств руководителя» (юрист, 1964 г. р.). 
Преемственный восходящий тип карьеры рассказчицы и её лояльность социальному контракту с государством в качестве госслужащей сложились благодаря многим факторам, из которых наиболее значительными являются следующие: престижное образование в престижном вузе; сохраненный спрос на её профессиональные и бюрократические компетенции; принадлежность команде как микроструктуре, мигрирующей из учреждения в учреждение; личные амбиции и честолюбие, а также консервативные ценности стабильности и надежности.

\section{Социальный контракт предпринимателя}

Если учесть, что предприниматели, как новая в позднесоветское время социальная группа, внутренне дифференцированы по типу накопления, то каждому типу соответствует своя легитимация в общественном сознании, источники социального рекрутирования и траектории жизненных путей. В нашей выборке оказались представленными четыре типа накопления капитала:

- номенклатурная приватизация собственности на основные средства производства,

- аренда с последующим переходом средств производства в собственность трудовых коллективов предприятий и организаций,

- накопление как результат личной экономической инициативы,

- полулегальное обогащение.

\section{Типаж предпринимателя с номенклатурным прошлым}

Из подмосковной деревни и родом из крестьянской семьи, он совершает восходящую карьеру, окончив последовательно среднюю школу, милицейскую школу и поступив после небольшого рабочего стажа в престижнейший Институт международных отношений, окончив его, остался там работать. Затем следуют стажировка в Канаде, защита диссертации, профилирование по проблемам международных профсоюзов и работа в Женеве в одной из международных организаций:

«...Интересно было поработать в системе ООН, себя попробовать, это же по специальности в конце концов, был и сугубо меркантильный интерес - заработать на кооператив... Там я был секретарем партийной организации. Там у нас была элита...

...Раздражало постоянно, что все перед организацией равны и неравны, но в соответствии с занимаемым постом... Все время в нас убивали чувство справедливости, принципиальности... Понимал, что... (протест) ни к чему не приведет, ничего не даст, кроме неприятностей, поэтому все молчали. Сдаешь деньги - все молчали. Что значит 
“сдаешь деньги”?... У нас у всех же были ООН-овские оклады, но в посольстве никто не мог получать больше посла. Послы у нас... получали небольшую зарплату, хотя у них был личный повар, бесплатная еда, машины и прочее - это в расчет не принималось. Им давали всякие представительские, это тоже в расчет не принималось. Я, получая где-то 7 тыс. \$ в месяц, все это сдавал... Оставалось у меня где-то 1800 \$. Мы приходили в посольство и говорили: “Пришли сдавать деньги”. “Не сдавать, а получать”, - говорили нам. Вот как-то один профессор, медик приехал поработать в ВОЗ. И когда ему сказали, что надо сдавать, он сказал: “Вы знаете, деньги - ерунда, я бы конечно дал их, но как-то мне очень неприятно, что меня заставляют. Я понимаю, что не смогу больше работать здесь, но сдавать не буду”. И он проработал до отпуска и из отпуска, конечно, не вернулся. Но за отпуск не сдавал и получил может быть больше, чем я за 6 с половиной лет, которые там пробыл (смеется)» (предприниматель, 1950 г. р.).

Резкие перемены, которые пришли в 90-х, вызвали у него переоценку ценностей.

«Все видишь, уже нет никакого идеализма. Я ведь верил, я же в партии пробыл... с 64-го, у меня хватило совести не выбрасывать билет. Одни в большей степени знали, другие - в меньшей. Слава богу, на нашем уровне всегда были возможности сомневаться. Понимаешь, ведь вера, что идолы на самом верху чисты, в какой-то степени компенсировала отсутствие веры во что-то иное... Все-таки ко времени выхода оттуда я уже не был наивным, верующим и честным, и принципиальным. Это как-то стиралось, стиралось, стиралось... Но пройдя через все это, нет чувства ущербности... ты все знаешь, все видел, тебя ничем не удивишь. Это хорошее чувство... А хочется каких-то новых ощущений... Подвернулся мне Центр по компьютерным сетям, и пошел я коммерческим директором... В конце концов все свернулось к торговле и посредничеству... Вначале меня это шокировало... когда в качестве посредника с какими-то консервами ко мне пришел бывший председатель Госплана, кошмар! Обычно с таких постов шли на солидные должности, под которые уже закладывали деньги, занимали ниши и т. д.» (предприниматель, 1950 г. р.).

Дистанция по отношению к власти, системе в целом, вызревавшая исподволь, трансформировалась в чувство освобождения, но не ранее, чем сломалась сама система. Её возможности наш респондент использовал до последнего момента. Он сменяет несколько фирм, в итоге сформировал собственную компанию.

«Сейчас - работа. И здесь даже не деньги выступают для меня на первом плане, хотя, конечно, это важно. Главное, среда совершенно 
другая, для меня более приемлемая, более интеллигентная... Все-таки, я как-то приспособился к этому (бизнесу) - это тоже доставляет какоето чувство удовлетворения... А то были периоды отчаяния, думал, я ни на что не способен. Мне было ужасно неудобно перед семьей...» (предприниматель, 1950 г. р.).

Здесь респондентом проговорены важные личностные итоги переломной эпохи - ценностные измерения его деятельности, причем в определенной иерархии: на первом месте для него новое поле самоутверждения, где он занимает одно из первых мест, затем успех/достижение («я смог это»), наконец, реализованная роль кормильца семьи.

\section{Типаж предпринимателя (накопление капитала в результате аренды с отчуждением средств производства)}

Харизматический характер этого человека сыграл свою роль, чтобы увлечь группу единомышленников и создать коллектив, вроде внешне и не отличающийся от других фирм, наводнивших рынок 90-х. Но внутренние взаимоотношения среди сотрудников, внутренние конвенциональные правила, рационализирующие работу - плод активности, в первую очередь, нашего рассказчика. Его отец - железнодорожный инженер, мать - медсестра, обе ветви - из крестьян, с большой тягой «наверх».

«Я не мог найти стержень, смысл жизни. Мне повезло, в армию тогда не взяли. Структурировался я через другое, связался с братьями-путешественниками. Начал ходить в походы, это была моя отдушина, мой мир. Тогда и снаряжение сами изготавливали. Первое путешествие было в Забайкалье, сплавлялись по реке. Год проработал в Институте физики, хороший институт, интересная работа и свободный график можно было 4 раза в году путешествовать... Но начались новые времена... Мы начали как бы чуть-чуть заниматься коммерцией. Что-то делать и продавать. Начали делать туристское снаряжение. Что мы могли еще делать? То, что нам было интересно. Потом поняли, что работать в двух местах невозможно. Все были свои, знакомые по туристскому клубу. Потом свою контору открыли, делали катамараны, средства сплава, потом открыли швейный цех и стали шить камуфляжную одежду. У нас качественная продукция и низкие цены, что позволяет нам держаться на рынке...» (предприниматель, 1965 г. р.).

Словосочетание «новые времена» покрывает по смыслу пространство смены вех социального контракта: хорошая и интересная работа со свободным графиком, гарантированная государством, сменилась на коммерческие опыты. «Что мы могли еще делать?» - фраза респондента говорит о единственно возможном пути заработать. В личностном плане, поиски 
смысла жизни завершились самоидентификацией с группой туристов, вернее теми групповыми ценностями, которые стоят за «туристским» образом жизни. Герой из ценностей досуга фактически делает ценности новой трудовой жизни. Соответственно, ценности и человеческие качества, прошедшие отбор в походах туристов, закладывались в основу кадрового отбора для этой фирмы:

«...Все оттуда пошло... Мы набирали туристов... А туризм - большая кузница кадров. Это тот пласт людей, которым была нужна внутренняя свобода, и он породил людей непритязательных, с повышенной жизнеспособностью, выносливостью, целеустремленностью. Но мы их уже всех выбрали (в смысле исчерпали) и не можем сейчас набрать по конкурсу... Лучшие кадры заложены в этой среде. Конечно, я там записываю, что он там закончил... Но в конце концов человека подбираешь, нравится он тебе или нет» (предприниматель, 1965 г. р.).

Но ситуация на фирме не осталась герметичной, и взаимоотношения в коллективе, как и взгляды респондента, подверглись эрозии, вызванной как макроэкономическими влияниями, так и капиталистической этикой труда:

«...В принципе я знал, что очень опасно приглашать на работу близких людей, друзей... У нас была однажды проблема с близким другом не сработались. Так и разошлись... Мне кажется, он просто поменялся. Зачастую люди в работе и на отдыхе разные. Если я чувствую, что человек любит работу, я многое ему прощу, потому что мы на этой почве в контакте» (предприниматель, 1965 г. р.).

В последних приведенных отрывках манифестируется новое социальное содержание, новые смыслы, порожденные российской рыночной реальностью. При всем стремлении удерживать на плаву микроклимат друзей-единомышленников, рассказчик - в первую очередь, совладелец-директор фирмы, озабоченный ее процветанием. Это заставляет его взглянуть иначе на формальные/неформальные отношения.

«...Было мудро решено в свое время - дележка зарплаты, даже учредителям - все было отдано мне на откуп. Никто не знает толком, кто сколько чего. Мы решили, что пусть будет один человек и он один решает. Я предложил такую схему и все согласились...» (предприниматель, 1965 г. р.).

В этом нарративе ярко подана идея авторитарного руководства, упакованная в коллективистские ценности. Персонифицированное «я» возникает только в конце секвенции и с целью продемонстрировать лишь внешний толчок общему решению. В действительности, фоновая практика являет собой пример единоличного решения одного из самых острых 
вопросов - распределения денег. Интересно то, что схватывается процессуальность изменений: туристские коллективистские нормы еще воспринимаются как ценность, но, одновременно, в недрах практики вызревают другие рациональности, отвечающие рыночным потребностям.

\section{Типаж предпринимателя (накопление капитала как результат личной экономической инициативы)}

Наш рассказчик - владелец строительной фирмы. Родом из провинции, из семьи педагогов, отец - директор школы. По воспоминаниям, «я не считал отца авторитарным, был раскрепощен, много воли имел». Окончив технический институт и аспирантуру в Москве, обзаведясь семьей и двумя детьми, он оказался перед проблемой обеспечения семьи.

«...Пошел работать на кафедру. Наука была сопряжена с добыванием денег на предприятиях, хоздоговорах. В такой ситуации пробыл 2-3 года, разрываясь между чистой наукой и необходимостью делать какие-то дела, ведь так просто деньги не платят...» (предприниматель, 1964 г. р.).

Накопив небольшие деньги и активизировав околонаучные связи, он организует совместное предприятие. Уходит из института и открывает собственную фирму.

«...Там ограничивали мою свободу, мнение, предписывали, как себя вести... Я стал менее доверчивым, сдержаннее; хорошо доверять, но лучше проверять... Я считаю, что МИФИ дал мне ту логику, которая позволяет мне легко сменить специальность. Я думаю, что мог бы работать и в строительстве и в торговле... Проще за месяц обучить МИФИ-ста чему угодно, чем брать профессионала и с ним работать... Необходима, на той работе, которой занимаюсь... какая-то совокупность минимальных знаний, там, по бухучету, по финансовому делу, банковскому, по работе с недвижимостью, юридические моменты очень нужны... И вот этот пробел в знаниях приходится возмещать чисто опытным путем... на ходу» (предприниматель, 1964 г. р.).

В приведенной секвенции представлены ориентация на личную самостоятельность и независимость в совокупности с тем типом образования (МИФИ), которое конвертируется в свободу предпринимательства, широту маневразанятостивответнапотребностирынка. Примечательното, чтоздесь проговаривается конструктивистская установка на «возмещение» востребованных образовательных навыков при базовой рациональности образованного физика-инженера (работник-трансформер). Чисто институционально, его история бизнеса также демонстрирует поступательное накопление автономности и самостоятельности (институт - хоздоговора - совместное 
предприятие - собственная фирма). В отношении социальной контрактации этот типаж предпринимателя демонстрирует необходимые для маневра занятости ресурсы, позволяющие отвергнуть неудовлетворяющую прежнюю схему и развернуться/освоить новую, рыночную, в которой меньше государственного патронирования, но больше свобод.

\section{Типаж предпринимателя (полулегальное накопление капитала)}

Инженер-программист, отец троих детей, тематизирует жизненную ситуацию человека, занявшегося спекулятивной торговлей. Вместе с женой, они оба утратили работу в классической ситуации 90-х: кризис неплатежей, бюджетное недофинансирование. Рассказчик занялся неразрешенной торговлей с рук, потом челночным бизнесом, затем оптовым, на грани легальности и нелегальности.

«Мы решили организовать какое-то свое предприятие. Отыскали несколько вариантов: самим открыться, под кем-то работать, под какой-то организацией... Потом стали открывать на молочной кухне компанию по продаже памперсов, решили, что это может дать объемную работу... Только когда мы уже начали работать с этим делом, то увидели, что там еще кто-то работает. Но ниша еще не была заполнена, но у нас не хватало организационного опыта, а бизнес, которым мы занимались, был неформальным. Нелегальный. Он не носил криминального характера, но он был нелегальный. Большинство людей прошло именно этот путь от нелегального бизнеса к легализации...» (предприниматель, 1962 г. р.).

Поиск своей ниши и нового культурного поля для самоутверждения выводит рассказчика в иное пространство, где представления о законности достаточно размыты, а представители власти - коррумпированы. Он пытается выстраивать новые для себя договорные начала, в которых уже нет места патронажу государства, а есть баланс зависящих от него взаимоотношений на основе рыночных обязательств.

«Я стал лучше разбираться в жизни, лучше понимать, какие этапы надо пройти, чтобы сделать дело. Понял, что такое заниматься делом, а не просто где-то сидеть... Никто мне 5-го и 20-го не принесет деньги на блюдечке с голубой каемочкой. Приходится самому адаптироваться и делать... У нас есть сложившиеся поставщики, места, склады, где мы закупаем товар. Взаимоотношения самые нормальные, человеческие. Потому что они делают дело, и мы делаем дело. Вот я делаю деньги ко мне соответствующее отношение. Все-таки не может человек изначально плохой... стабильно делать деньги. Рано или поздно он где-нибудь проколется... Мне сейчас дают товар под честное слово, но при этом прошел достаточно большой период времени» (предприниматель, 1962 г. р.). 
Умение стабильно делать деньги выступает здесь интерсубъективным достижением рассказчика: он доказал не только себе, что он справился с этой задачей, но получил и признание других, выражающееся в кредите доверия. Этим позитивно завершилась смена его идентификации, произошедшая, когда он, технический интеллигент, пошел торговать на улицу. Потребность социального признания способствует и выкристаллизовыванию его понимания социального контракта:

«Здесь у нас нельзя честно зарабатывать, это не требуется... Да! Мы не честны в определенном смысле перед этим государством. Но и это государство в определенной мере не честно перед нами. Я лишь веду себя с ним так, как оно ведет себя со мной» (предприниматель, 1962 г. р.).

Его честность - феномен достаточно конвенциональный. Если государство не несет ответственности или меняет правила игры, то рассказчик пересматривает свои. Чье мнение для него референтно, так это ближний круг посредников, продавцов и покупателей, вовлеченных в его бизнес. Здесь он дорожит своей репутацией, которую нужно постоянно защищать в жесткой конкурентной борьбе («поехали с женой в отпуск, вернулись, а наших клиентов “увели"»).

В целом, лейтмотив со стороны бизнеса в части ожиданий от государства в основном сводится к самому простому - невмешательству, что гарантировало бы и стабильность. Государство в социальном контракте с бизнесом воспринимается предпринимателями эпохи 90-х не как партнер, от которого ожидается соблюдение правил, обеспечение среды взаимодействия, а, скорее, как потенциальная угроза постоянного вмешательства и переопределения правил игры. Поэтому от интервью к интервью звучал призыв не вмешиваться, а вовсе не ожидания помощи. С очевидностью, такой набор ожиданий свидетельствует о конфигурации неравновесного вертикального социального контракта 90-х, характеристикой которого является фактически забвение, если не попытка уклонения от контрактации: вы не вмешиваетесь, а мы работаем.

\section{Заключение}

Как показала ретроспекция опросов общественного мнения 90-х, легитимность решений, принимаемых властью в ту эпоху, была в кризисе. Кредит доверия сменялся общественным разочарованием, экономический фон приобретал временами угрожающий для правительства характер, вынуждающий к непопулярным шоковым мерам. Десятилетие 90-х поставило под сомнение прежнюю версию социального контракта как баланса ожиданий различных социальных групп населения. Теоретически, пересмотр девальвированного социального контракта был возможен, в первую очередь, в направлении нового набора институциональных правил игры, расширяющих 
пространство для социальных маневров и снижающих социальную напряженность в пороговый момент. Но был возможен и тот вариант пересмотра социального контракта, который инерционно длит преемственность с прежними патерналистскими ценностями, родственен с советским патерналистским комплексом, включающим социальную защиту и лояльность, что оказалось характерно для определенных социальных групп, таких как рабочие, наемные работники, госсслужащие. В отличие от них, предприниматели как наиболее самостоятельная и мобильная группа в обществе 90-х быстрее избавлялись от патерналистских установок и ожиданий и простраивали горизонтальные контрактные связи в бизнес-сообществе.

В целом, мы можем обоснованно предположить, что в эпоху 90-х имел место феномен кризиса легитимности власти, динамичная перестройка социальных контрактов, но синдром патернализма как якорная форма для прежней конфигурации вертикального социального контракта также был функционален в форме социальных ожиданий и инерции.

\section{Литература}

Артог Ф. Типы исторического мышления: презентизм и формы восприятия времени // Отечественные записки.

URL: http://magazines.russ.ru/oz/2004/5/2004_5_18.html (дата обращения: 08.09.2018)

Аузан А. Экономика всего. Как институты определяют нашу жизнь. М.: Манн, Иванов и Фербер, 2013.

Бьюкенен Дж. М. Сочинения. Т. 1: Конституция экономической политики. Расчет согласия. Границы свободы / Пер с англ.; гл. ред. Р. М. Нуреев. Фонд экономической инициативы. М.: Таурус Альфа, 1997. (Нобелевские лауреаты по экономике)

Вильцер X. История, память и современность прошлого: память как арена политической борьбы // Неприкосновенный запас. 2005. № 2-3 (40-41).

ВЦиОМ. База результатов опросов россиян «Архивариус» URL: https://wciom.ru/database/ baza_rezultatov_oprosa_s_1992_goda/ (дата обращения: 12.10.2018)

Гайдук К., Ракова Е., Силицкий В. Социальные контракты в современной Беларуси. Минск, 2009.

Грушин Б. А. Четыре жизни России в зеркале опросов общественного мнения. Очерки массового сознания россиян времен Хрущева, Брежнева, Горбачева и Ельцина. В 4 кн. Жизнь 2-я: Эпоха Брежнева. Ч. 2. М.: Прогресс-Традиция, 2006.

Дворкин Р. О правах всерьез / Пер. с англ.; ред. Л. Б. Макеева. М.: РОССпЭН, 2005.

Дискин И.Е. Институциональные рамки социального развития // Экономика России: теория и современность: материалы ІІ Чаяновских чтений, Москва, 2002. С. 83-95.

Капустин Б., Клямкин И. Либеральные ценности в сознании россиян // Полис. 1994. № 1. С. 68-92.

Клемин А. В. «Имиджевые эпитеты терминами не являются» // Современная Европа. 2015. № 5. C. $141-154$.

Кузьмин А. С., Мелвин Н. Дж. и Нечаев В. Д. Региональные политические режимы в постсоветской России: опыт типологизации // Политические исследования. 2002. №3. С. 142-155.

Курбатова М.В., Левин С.Н. Деформализация правил в современной российской экономике (на примере взаимодействия власти и бизнеса) // Terra economicus. 2010.T. 8. № 1. С.27-50.

Лавров А., Литвак Дж. и Сазерлэнд Д. Реформа межбюджетных отношений в России: «федерализм, создающий рынок» // Вопросы экономики. 2004. № 4. С. 75-83.

Лапина Н., Чирикова А. Стратегия региональных элит: экономика, модели власти, политический выбор. М.: ИНИОН РАН, 2000. 
Новгородцев Д. К экономической теории контракта. Красноярск: Красноярский государственный университет, 2006.

Нуреев Р. М. Социальные субъекты постсоветской России: история и современность // Мир России. 2001. № 3. С. 3-66.

Олейник А. Н. Институциональная экономика. М.: ИНФРА-М, 2000.

Перегудов С. П. Корпоративный капитал и институты власти: кто в доме хозяин? // Полис. 2002. № 5. С. 74-84.

Попов Н. «Лихие 90-е». Каким было общественное мнение в эпоху Ельцина. URL: http://kapitalrus.ru/articles/article/obschestvennoe_mnenie_v_epohu_elcina/ (дата обращения: 10.04.2018)

Радаев В. В. Новый институциональный подход и деформализация правил в российской экономике. М.: ГУ-ВШЭ, 2001.

Рогов С. М. Функции современного государства: вызовы для России // Свободная мысль. XXI. 2005. № 7. 56-68.

Ролз Дж. Теория справедливости / Под ред. В.В.Целищева. Новосибирск: Изд-во Новосибирского университета, 1995.

Сидорина Т. Ю. Перспективы социального контракта в современной России // Постсоветский институционализм - 2007: варианты институционального развития России - предпосылки, закономерности, перспективы. Сб. ст. Томск: Изд-во Томского государственного педагогического университета, 2008. Гл. 5. С. 86-103.

Филиппов А. Ф. Конструирование прошлого в процессе коммуникации: теоретическая логика социологического подхода. Препринт WP6/2004/05. Серия WP6. Гуманитарные исследования ИГИТИ, 2004.

Хальбвакс М. Коллективная и историческая память // Неприкосновенный запас. 2005. № 2-3 (40-41). C. 8-27.

Cook L.J. The Soviet Social Contract and why it Failed: Welfare Policy and Workers' Politics from Brezhnev to Yeltsin. Harvard University Press, 1993.

Hirschman A. "Exit, Voice, and the State"// World Politics, vol. 31, no 1 (October 1978), pp. 90-107.

Jedlowski P. Memory and Sociology. Themes and issues. Time and Society, 2001, no 10 (1), pp. $29-44$.

Дата поступления: 02.05.2019

\section{Social contract in the era of the $90 \mathrm{~s}$}

DOI: 10.19181/inter.2019.18.4

\section{Elena Rozhdestvenskaya}

Rozhdestvenskaya Elena - Doctor of Sociology, Professor of the Department of Sociology, the National Research University Higher School of Economics; Leading Researcher at the Institute of Sociology, FCTAS RAS, e-mail: erozhdestvenskaya@hse.ru

The article deals with the changing social contract in the era of the $90 \mathrm{~s}$. Combined several levels of analysis: reconstruction of the era of the 90 s by methods of public opinion polls and a qualitative analysis of narratives about the era of the $90 \mathrm{~s}$, representatives of various social groups (workers, employees / civil servants, entrepreneurs). If public opinion polls the most important events of the era, which made up the historical memory of the generation who participated in the changes of Russian society, the narratives of the 90s contain a description of the experience and reflection of social actors regarding the limits and possibilities of this era. The conceptual framework of the study describes the concept of a social contract as a balance 
of expectations between its performing individuals and social institutions. The social contract is operationalized as a set of action strategies that have been implemented by individuals and are the subject of their memories in the biographical interview mode. As a result of the study, a specification was made for representatives of the above-mentioned social groups of various social contracts that have undergone devaluation and changed during the $90 \mathrm{~s}$.

Keywords: era of the 90 s, social contract, labor contract, social groups, biographical interviews

\section{References}

Artog F. (2018) Tipy istoricheskogo myshleniya: prezentizm i formy vospriyatiya vremeni [Types of historical thinking: presentism and forms of time perception]. Domestic notes. URL: http://magazines.russ.ru/oz/2004/5/2004_5_18.html (appeal date: 09/08/2018)

Auzan A. (2013) Ekonomika vsego. Kak instituty opredelyayut nashu zhizn' [Economy of everything. How institutions define our lives]. M: Mann, Ivanov and Ferber.

Buchanan J.M. (1997) Konstitutsiya ekonomicheskoy politiki. Raschot soglasiya. Granitsy svobody [Works. The constitution of economic policy. Calculation of consent. Frontiers of Freedom], in: Buchanan J. M. Sochineniya, vol. 1. M: Taurus Alpha.

Cook L. J. (1993) The Soviet Social Contract and why it Failed: Welfare Policy and Workers' Politics from Brezhnev to Yeltsin. Harvard University Press.

Diskin I. E. (2002) Institutional Framework for Social Development [Institutional framework of social development]. Economy of Russia: Theory and Modernity: Proceedings of the II Chayanov Readings, Moscow, pp. 83-95.

Dvorkin R. (2005) O pravakh vser'yoz [About Rights Seriously]. Trans. from English; ed. L. B. Makeeva. M: ROSSPEN.

Filippov A. F. (2004) Konstruirovaniye proshlogo v protsesse kommunikatsii: teoreticheskaya logika sotsiologicheskogo podkhoda [Constructing the past in the process of communication: the theoretical logic of a sociological approach]. Preprint WP6/2004/05. WP6 series. Humanitarian research IGITI,.

Gaiduk K., Rakova E., Silitsky V. (2009) Sotsial'nyye kontrakty v sovremennoy Belarusi [Social Contracts in Modern Belarus]. Minsk.

Grushin B.A. (2006) Chetyre zhizni Rossii v zerkale oprosov obshchestvennogo mneniya. Ocherki massovogo soznaniya rossiyan vremen Khrushcheva, Brezhneva, Gorbacheva i Yel'tsina [Four lives of Russia in the mirror of public opinion. Essays on the mass consciousness of Russians in the times of Khrushchev, Brezhnev, Gorbachev and Yeltsin] (in 4 books). 2nd Life: The Epoch of Brezhnev. Part 2. M: Progress-Tradition.

Halbwachs M. (2005) Kollektivnaya i istoricheskaya pamyat' [Collective and historical memory]. Indispensable reserve, № 2-3 (40-41), pp. 8-27.

Hirschman A. (1978)“Exit, Voice, and the State”. World Politics, vol. 31, no 1, October, pp. 90-107.

Jedlowski P. (2001) Memory and Sociology: Themes and issues. Time and Society, no 10 (1), pp. 29-44.

Kapustin B., Klyamkin I. (1994) Liberal'nyye tsennosti v soznanii rossiyan [Liberal values in the minds of Russians]. Polis, no 1, pp. 68-92.

Klemin A. V. (2015) "Imidzhevyye epitety terminami ne yavlyayutsya" [Image epithets are not terms]. Modern Europe, no 5, pp. 141-154.

Kurbatov M.V., Levin S.N. (2010) Deformalizatsiya pravil v sovremennoy rossiyskoy ekonomike (na primere vzaimodeystviya vlasti i biznesa) [Deformalization of the rules in the modern Russian economy (for example, the interaction of government and business)]. Terra economicus, vol. 8, no 1, pp. 27-50. 
Kuzmin A. S., Melvin N. J., Nechaev V. D (2002) Regional'nyye politicheskiye rezhimy v postsovetskoy Rossii: opyt tipologizatsii [Regional political regimes in post-Soviet Russia: the experience of typologization]. Political studies, no 3, pp. 142-155.

Lapina N., Chirikova A. (2000) Strategiya regional'nykh elit: ekonomika, modeli vlasti, politicheskiy vybor [Strategy of regional elites: economics, power models, political choice]. M: INION RAS.

Lavrov A., Litvak J., Sutherland D. (2004) Reforma mezhbyudzhetnykh otnosheniy v Rossii: "federalizm, sozdayushchiy rynok" [Reform of intergovernmental relations in Russia: "federalism creating a market"]. Voprosy Economiki, no 4, pp. 75-83.

Novgorodtsev D. (2006) Kekonomicheskoy teorii kontrakta [To the economic theory of the contract]. Krasnoyarsk: Krasnoyarsk State University.

Nureev R. M. (2001) Sotsial'nyye sub"yekty postsovetskoy Rossii: istoriya i sovremennost' [Social subjects of post-Soviet Russia: history and modernity]. World of Russia, no 3, pp. 3-66.

Oleynik A. N. (2000) Institutsional'naya ekonomika [Institutional economy]. M: INFRA-M,.

Peregudov S. P. (2002) Korporativnyy kapital i instituty vlasti: kto v dome khozyain? [Corporate capital and government institutions: who is the boss?]. Polis, no 5, pp. 74-84.

Popov N. (2018)“Lihiye 90-e." Kakim bylo obshchestvennoye mneniye v epohu Yeltsina ["Dashing 90s." What was the public opinion in the Yeltsin era]. URL: http://kapital-rus.ru/articles/article/ obschestvennoe_mnenie_v_epohu_elcina/ (circulation address: 04/10/2018)

Radaev V.V. (2001) Novyy institutsional'nyy podkhod i deformalizatsiya pravil v rossiyskoy ekonomike [New institutional approach and deformalization of rules in the Russian economy]. M: GU-HSE.

Rogov S. M. (2005) Funktsii sovremennogo gosudarstva: vyzovy dlya Rossii [Functions of the modern state: challenges for Russia]. Free thought, XXI, no 7, pp. 56-68.

Rawls J. (1995) Teoriya spravedlivosti [Theory of Justice]. Ed. V.V. Tselishcheva. Novosibirsk: Novosibirsk University Press,.

Sidorina T. (2008) Perspektivy sotsial'nogo kontrakta v sovremennoy Rossii [Prospects for a social contractin modern Russia], in: Post-Soviet Institutionalism - 2007: Options for the InstitutionalDevelopment of Russia - Prerequisites, Laws, Prospects. Digest of articles. Tomsk: Tomsk State Pedagogical University Publishing House, ch. 5, pp. 86-103.

VCIOM. (2018) Baza rezul'tatov oprosov rossiyan "Arkhivarius" [Database of polls results of Russians "Archivist”]. URL: https://wciom.ru/database/baza_rezultatov_oprosa_s_1992_goda/ (appeal date: 10/12/2018)

Wilzer H. (2005) Istoriya, pamyat' i sovremennost' proshlogo: pamyat' kak arena politicheskoy bor'by [History, memory and the present of the past: memory as an arena of political struggle]. Immunity reserve. no 2-3 (40-41).

Received at: 02.05.2019 